\title{
Chapter 12 \\ Childless at Age 30: A Qualitative Study of the Life Course Plans of Working Women in East and West Germany
}

\author{
Laura Bernardi and Sylvia Keim
}

\subsection{Introduction}

In Germany, the low birth rate and the difficulties women face in reconciling work and family life are frequently discussed by policy-makers. At the heart of the current debate on these issues is the legal entitlement of children under 3 years of age to a place in nursery school, which has been in effect on the national level since August 2013. The qualitative improvement in childcare and the increase in the uptake rate of Elterngeld (parental benefits) for both parents are also high on the political agenda. The aim of these policies is to facilitate the reconciliation of work and family life and the re-entry of mothers into employment as early as possible after childbirth, and thus to make it easier for young adults to pursue an employment career without having to forgo parenthood.

However, the interplay of employment history and fertility behavior, and the ways in which the subjective meanings attached to work trajectories are connected to thoughts and decisions about starting a family, are issues that have so far been little researched (Witzel and Kühn 2001: 56). Relatively few authors have examined the question of whether differences in meanings can explain the differences in

\footnotetext{
L. Bernardi $(\bowtie)$

LIVES, Faculty for the Social and Political Sciences, University of Lausanne,

Lausanne, Switzerland

e-mail: laura.bernardi@unil.ch

S. Keim

Institute of Sociology and Demographic Research, University of Rostock,

Rostock, Germany

e-mail: sylvia.keim@uni-rostock.de
} 
behavior between young adults in East Germany and their counterparts in West Germany. ${ }^{1}$ The work biographies and the family formation patterns of East and West Germans, especially of women, differed considerably. The focus of our analysis is on young women who grew up in the two different systems, and were thus exposed to contrasting family models. How do these differences in upbringing influence the life course plans and arrangements of these women after unification? How do these women envisage combining family formation and employment? Do these women have the same values, norms, attitudes, and behaviors as those of their parents' generation? According to Bourdieu, this legacy of the past could be regarded as an "inertial effect". He stressed that because socialization affects the formation of attitudes and values, as well as the meanings attached to certain behaviors and the range of action, values and behavior may persist after the macro-societal conditions have changed.

Our analysis in this chapter is based on the life stories of young employed women who were socialized in the former East and West Germany, experienced unification as teenagers, and were around age 30 at the time of interview. Over the course of four qualitative case studies we compare East and West German women who are still childless but who want to have children. We examine which family formation pathways these women prefer, the reasons why they have so far remained childless, and their attitudes and perceptions regarding the compatibility of motherhood and paid employment.

In the following section we briefly describe the institutional and demographic peculiarities of the two German states before and after reunification. In the third section we outline the theoretical background of our investigation and introduce our empirical data. In the fourth section we present four case studies of childless women from East and West Germany. In the concluding section we discuss our results and suggest topics for future research.

\subsection{The Legacy of Different Socio-political Systems: Starting a Family in West and in East Germany}

Before German unification, fertility behavior of East and West Germans differed profoundly; thus, we are dealing with two distinct demographic regimes. The term regime implies that these differences in family behavior were shaped by different institutional contexts. One of the most important differences in the realm of family behavior was that the East German government supported maternal full-time employment by providing extensive and easily accessible childcare services.

\footnotetext{
${ }^{1}$ Andreas Witzel and Thomas Kühn, for instance, examined the life courses of young adults from two regions in West Germany that have different labor market conditions. They found that women, especially after reaching age 30 , experience an increased subjective pressure to have children. Career-oriented women "look for solutions which are compatible with family life via 'decelerated' careers" (Witzel and Kühn 2001: 78).
} 
The centrally planned economy guaranteed that both men and women would have reliable and stable employment. Most women had their first child early in their life course, and returned to full-time work after the so-called "Babyjahr". In most cases mothers interrupted their employment for 1 year only. Women seldom had the option of taking a longer break from employment or of shifting to a part-time schedule, and few women spent more than short periods of time as a full-time homemaker (Falk and Schaeper 2001: 188). In contrast, the institutional framework in West Germany supported the model of the married couple with a gendered division of work: i.e. the husband was the principal earner while the wife was a homemaker and mother who was employed part-time or not at all. On average, women in West Germany were considerably older than their counterparts in East Germany at the time of family formation. About $20 \%$ of the women in West Germany remained childless, compared with just $10 \%$ in East Germany (Kreyenfeld and Konietzka, in this volume).

Under the terms of the Unification Treaty, the East German institutional, economic, and political systems were replaced by the West German systems. However, the eastern German Länder remained distinct from West Germany in a number of ways. In particular, in the eastern German Länder childcare services, organized and financed mainly by the municipalities, continued to be widely available (Kreyenfeld 2003; Statistische Ämter des Bundes und der Länder 2015). The annual birth rate fell dramatically in the years immediately after unification (Eberstadt 1994; Witte and Wagner 1995). Although the total fertility rate in East Germany converged with the West German rate after a few years, and even surpassed it slightly since 2008 (Statistisches Bundesamt 2012: 15), some differences between the two parts of the country in the average age at first birth remain. Moreover, women in East Germany are still less likely to be childless than women in West Germany. In addition to being younger when they have their first child, women in East Germany are more likely than women in West Germany to be living in a non-marital partnership at the time of family formation (Kreyenfeld and Konietzka 2010; Huinink et al. 2012; Statistisches Bundesamt 2012). Meanwhile, women in West Germany, who tend to have negative opinions of working mothers, are considerably less likely than women in East Germany to be in full-time employment (Wenzel 2010; Huinink et al. 2012). Given these differences, we conclude that despite the convergence of the political and institutional frameworks of the two parts of the country, two distinct demographic regimes continue to exist. It can, however, also be argued that these differences are merely symptomatic of the critical transitional period, and that behavioral patterns in East and West Germany will eventually converge (Witte and Wagner 1995; Beck-Gernsheim 1997; Kreyenfeld 2004). Yet when and how this assimilation process might occur is currently unclear. The hypothesis of assimilation fails to provide an explanation for the persistent differences in behavioral patterns between the two parts of the country, such as the much higher ratio of unmarried births in East than in West Germany.

In this paper, we contribute to the debate surrounding this ongoing East-West gap in fertility behavior by focusing specifically on the attitudes and life course plans of women who were socialized in the former East and West Germany, and who reached 
their teenage years around the time of German unification. How has the experience of being socialized in a particular regime shaped the life course plans of women in the two Germanies? Is there a legacy of the former East German regime that is visible in the attitudes and behavior of young East Germans, similar to an 'inertial effect' of socialization as described by Bourdieu (1984)? Or was German Reunification able to override particular features and attitudes of the "Reunification Cohorts"?

\subsection{Theoretical and Empirical Background}

Based on the concept of habitus, Pierre Bourdieu posited that socialization has an "inertial effect" (1984). Bourdieu used habitus to describe a permanent behavioral disposition that emerges through socialization in a given social environment. By means of his or her habitus, the individual is supposed to incorporate the social norms of the environment, to set his or her preferences, and to act accordingly. It is therefore assumed that the individual's range of action is not restricted by material living conditions alone. Instead, the individual's internalized norms regulate his or her perceptions of which actions are or are not appropriate. It is further assumed that the habitus is very stable, because the individual's perceptual categories and preferences are largely shaped in an unconscious manner through the socialization process.

The concept of ideology developed by Göran Therborn points in the same direction. He emphasized that behavior is limited not just by external circumstances, but also by the imagination of "what exists," "what is good," and "what is possible and impossible" (Therborn 1980: 18); and that multiple ideologies may exist simultaneously within a single culture.

The inertial effect is also conceptualized in the schema theory by Roy D'Andrade. This theory seeks to explain how the socialization process (e.g., acculturation) within a certain social (or cultural) group translates into wishes, motivations, and strategies for action. D'Andrade also stressed the resistance to change: a schema is crystallized in the memory and appears to be prototypical (D'Andrade 1997: 29). Like the concept of habitus, the schema theory posits that the individual perceives socially determined dispositions on an individual basis only. All of these theories assert that the individual behavioral repertoire is restricted by (a) the availability of material resources; as well as by (b) subjective perceptions of possible and appropriate behavior, which originate from the individual's experiences during socialization and in a certain social environment.

The availability of material resources can be analyzed empirically using indicators such as the individuals' socioeconomic characteristics and access to infrastructure. Meanwhile, the complex interaction of consciously chosen and internalized behavior, as described by the term habitus, can be better captured by an interpretative analysis of unstructured interviews in which the individual reconstructs his or her own biographical experiences and makes predictions about his or her future development. 
As part of our research project on social influences on family foundation in East and West Germany, we conducted qualitative interviews with more than 100 young women and men in 2004 and 2005. The interviewees grew up in either Lübeck or Rostock, and had either an intermediate or a higher educational degree. We chose these two cities because they are similar in many respects, despite having been subject to two different political regimes for 40 years during the division of Germany. For example, both are port cities in northern Germany that were part of the Hanseatic League. The dominant religion in both cities is Protestant. Moreover, both Lübeck and Rostock have approximately 200,000 inhabitants, and the unemployment rate in both was relatively high during the period of our fieldwork (13.8\% in Lübeck compared to $7.6 \%$ in West Germany; $18.2 \%$ in Rostock compared to $17.7 \%$ in East Germany in 2002). During the interviews, the respondents were encouraged to provide an account of their life up to that point, and to describe their plans for the future. The respondents were also asked systematic questions about the issue of family formation. ${ }^{2}$

Our analyses show that women who live in Rostock and Lübeck have very different ideas about what kinds of employment situations and levels of economic security are prerequisites for having a child (Bernardi et al. 2006). Of particular interest to us in this chapter are the views on starting a family and the reconciliation of work and family life among women who are highly qualified and in full-time employment. We focus on childless women who want to have children. ${ }^{3}$ Since socioeconomic characteristics, such as educational level and income, have a considerable influence on both the material resources and the attitudes and perceptions of the individual, we restrict our study to women with similar socioeconomic profiles. Our sample selection allows us to attribute different narrations, especially those related to material life conditions, to different perceptions, attitudes, and values regarding family formation.

\subsection{Childless Women from East and West Germany: A Comparison}

How did these childless women, who were socialized in different fertility regimes and were about to enter their thirties, see their previous life experiences and their future life path? What similarities and differences are revealed in our interviews of women from East and West Germany? Based on our hypothesis of an inertial effect, is it possible to attribute these differences to differences in socialization in East and West Germany?

\footnotetext{
${ }^{2}$ Detailed information on the selection of the interviewees and the data collection method can be found in Bernardi et al. (2014).

${ }^{3}$ Only a few of our interviewees said that they definitely do not want to have children. We conducted a separate analysis of these interviewees, and therefore excluded them from this essay.
} 
To allow us to focus on narrations of a complete life path, instead of on fragmented aspects of each story, we confine our investigation to four case studies: two women from Rostock and two women from Lübeck, who are similar in many ways. This approach helps to ensure that the differences in views on family formation are not primarily attributable to differences in living conditions. The first two women we compare both had a safe employment situation and moderate career ambitions. At the time the interview was conducted neither of the women was in a relationship suitable for starting a family (the interviewee from Lübeck was single while the respondent from Rostock was in a relationship which she considered unstable). The other two women we compared were similar in terms of their mobility experiences and career ambitions. At the time of the interview they had been in the same partnership for multiple years and wanted to have children with their partner. Thus, while each woman has her own story, our case studies exemplify the main differences between all of the interviewees from Lübeck and Rostock.

\subsubsection{Antje from Rostock: Refusal to Engage in Family Planning: "I Hate Planning"}

Antje is 29 years old. She grew up in Rostock, and graduated from high school and university in the city. She would have preferred to have stayed there, but-like many other women her age - she moved to nearby West Germany 5 years previously to take a job. When her first employer went bankrupt 2 years later, she looked for and easily found a new job. She is currently employed full-time and has a high disposable income. Although she does not consider her work to be exciting ("a lot of paperwork"), she describes her job as safe and her salary as appropriate. While she sometimes looks half-heartedly for another job, she expects to stay where she is for at least the next few years:

"It's a rather safe place, but I do not really want to say that I want to grow old there. I feel I am still too young to stay in such an administrative position for years."

Antje has been in a relationship for 3 years, but does not live with her partner, although he would like to cohabit. She describes her relationship as a "pending action" and is not certain how it will develop:

"I do not really have a plan, I honestly have to say. Maybe it's because the relationship is not that good at the moment, or maybe I simply have a little tick, that I don't want this [moving in together]. On the other hand I kind of like it this way [as it is]."

Antje states that having her own family will become an issue "certainly at some point in time," but not at the moment: "I am only 29 years old." Yet, she reports having an increased interest in children:

"I find children very, very beautiful (...) maybe it's my hormones; one likes to look [at little children]. Don't ask why, it's like that." 
She takes it for granted that she will continue to work after becoming a mother. She complains about the poor "childcare in the West," and hopes that in the future companies will do more to help women balance work and family life. Antje's image of a family coincides with the traditional family model in the former East Germany, which featured a full-time working mother. Antje's demand for adequate public childcare and for more family-friendly company policies also draw on this family model.

Throughout her narration, Antje refuses to make long-term plans. This systematic rejection of planning for the future is evident in almost all parts of the interview in which she talks about her work life or her partnership:

"For the love of God, I hate planning. I would start panicking if things did not work out accordingly [laughs]. (...) Well, because then the people, if they plan, obviously also become frustrated eventually, if it doesn't happen the way they hoped. And then the life crises start [laughs]."

Even when asked about a possible timeframe for starting a family, she refuses to make any specific plans:

"I don't want to somehow choose a time now, but I also don't want to be an old maid."

Although she wants to have a child, Antje cites her age as the main reason for her childlessness, as she believes she can wait a few years before having a child. However, the instability of her partnership also seems to play a role in her indecision, as the following quote illustrates:

"I think if the circumstances were right, maybe I wouldn't plan things that precisely. But at the moment, I wouldn't like to have it [the child] by myself right now. (...) The partner should be right at least, I don't just need some sperm donor (...) and I also think that one should also live together. Yes, I think the relationship should be in place."

According to Antje, the "right circumstances" for motherhood include being in a harmonious partnership: if she had a suitable partner, she would not need to have a precise plan for starting a family. It is clear that she does not consider her current partner to be the "right" one. She does not, however, explain what bothers her about her current partner, or describe what qualities a suitable partner would have. She mentions her job as being another factor in her decision about when to start a family:

"In my current job, I think I could take a break at any point for a certain period of time and then go back. I wouldn't worry too much about that."

Since her current job allows her to take parental leave and come back afterwards, the criterion of having a job suitable for starting a family has already been met. Thus, for Antje the issue of how to reconcile work and family life has been resolved.

As a counterpart to Antje's story, we now look at the story of a young woman from Lübeck. She has a very different image of the family, and describes a precise set of conditions under which she hopes to start a family. 


\subsubsection{Miriam from Lübeck: Family Planning Based on the Main Breadwinner Model: "I Envision it Like This, That I Will Definitely Stay Home"}

Miriam is single, 30 years old, and has an open-ended full-time job. Although she is proud of her occupational achievements, she ascribes them more to coincidence or to external pressure than to her own efforts. She sees herself as lazy, and is not interested in any career objectives. She has considered continuing her education, but has repeatedly postponed doing so because she believes it would be too arduous. She is very happy with her current job, and has become friends with her boss and some of her colleagues. She currently views her job as relatively safe, but given the high rate of unemployment in Lübeck, she is aware that this can change quite quickly.

Miriam has wanted to have children for some time, and the main topic in this interview is her lack of a partner with whom she can start a family. When she talks about family, Miriam has the traditional West German family model in mind: the woman is a full-time homemaker or works part-time, while the husband is the main breadwinner.

"If everything is great and all of the preconditions are met, I actually envision that I will definitely stay home and play mom as long as I feel like it. And then I can go back to work. I don't think that these three years are enough for me. I think I could even go longer."

This plan seems to reflect the experiences of her own mother, who raised four children while her husband worked, and did not have a job until the youngest child became a teenager. Miriam believes that taking care of children is the responsibility of the mother. She rejects the idea of involving her male partner in childcare (e.g., paternity leave) or putting her children in day-care:

"If I actually give birth to a child, I would also like to enjoy it somehow."

Since having a secure financial foundation is very important for Miriam, she wants her partner to have a salary that is large enough to allow her to stay home:

"By all means, if I actually plan this, if I plan to have children, then I absolutely would like to be financially secure so that I don't have to sacrifice so much."

Here it becomes evident that she would like to have a firm foundation before starting a family. Her planning also extends to the life of her partner: he is supposed to have career ambitions as well as a job (or the prospect of a job) which provides financial security and a good income. Her former partners were not suitable because they were not sufficiently career-oriented, they did not want to have children, or they did not want to take on the role of the main breadwinner:

"I would have provided him with all the opportunities; we could have moved into a smaller apartment so he could study. But he didn't want to. (...) I have always, well we have also spoken about it, what we would do if we had children now, how would we finance this. I would have had to have gone back to work immediately. (...) That was another thing which bothered me, because it was never clear what happens then. (...) And yes, at this age, at 30, 
one starts to think. I thought about whether I really wanted to have a family, children with him. Nah! I didn't."

As she wants to have children, Miriam attributes her childlessness to the lack of the right partner. Her goal is to find a partner who shares her views concerning role allocation within the family and the preconditions for starting a family, and who is able to provide the desired financial security.

The case studies of Antje and Miriam illustrate that the family models that were dominant in the former East and West Germany persist after unification, and that views on long-term life course planning can differ considerably in the two parts of the country. The following two case studies of women who have been living in a partnership for years are similar to the first two case studies. They also show that women in the East and the West differ in their views on family models and longterm family planning. Both women are highly qualified university graduates with excellent career prospects. Now they are facing the issue of how to reconcile work and family life.

\subsubsection{Kristin from Rostock: Egalitarian Gender Roles and the Impossibility of Reconciling Work and Family Life: "A Great Job and Family—How is that Supposed to Work Out?"}

Kristin is 29 years old and grew up in Rostock. After graduating from high school she moved several times. First she moved to another town in East Germany to attend university, and then to a town in West Germany to attend a different university. After graduating from university she moved to yet another town to enroll in a doctoral program. She got a full-time job a few months previously, and again lives in a town in East Germany. She has been in a partnership for 7 years. She and her partner have lived together for certain periods of time, while in other periods they have had a long-distance relationship and saw each other only on the weekends. They have been living together for 9 months now:

"I have reached the point at which we have been living together for a longer period of time than we commuted, if I don't move again [laughs]."

The main issue she raises in her interview is the difficulties she faces in combining the demands of her career, including the need to move frequently, with her desire to live with her partner:

"On the one hand I would like to have a great job, on the other hand I want to live together."

She is always forced to make compromises. Although she lives with her partner, her workplace is relatively far $(70 \mathrm{~km})$ from their home, and she is not completely satisfied with her job: 


\begin{abstract}
"It was clear to me beforehand that this isn't my dream job, but rather an attempt to somehow reconcile everything (...) Since we are living together at the moment, I am sticking with it for now. On the other hand if the job becomes very frustrating, at some point I will start thinking about living apart again."
\end{abstract}

As she has so far failed to find a way to combine living with her partner with having the right job, starting a family seems even less possible to her:

\begin{abstract}
"And if one wants to have something like a family, [should the parents then] travel? How is this supposed to work? Should the parents decide to live alone as 'voluntarily single parents'? (...) I find this very, I can't, well I find this very, very difficult at the moment. (...) We actually want to have children. (...) And a relationship based on traveling, like I said: who takes the children? Me or you or maybe in the middle? How does one organize something like this?"
\end{abstract}

Like Antje from Rostock, Kristin takes for granted that she will continue to work and pursue her professional ambitions after becoming a mother. And like Antje, she does not want to have to plan to start a family, and lacks precise ideas about how and when to have a child. While she recognizes that the amount of time she has to become pregnant is limited, this thought does not inspire her to engage in more precise planning:

"So far I have always felt young enough, that the edge is still far away."

The young woman from Lübeck we will introduce in the following case study has also faced challenges in reconciling her career ambitions and her desire to become a parent. However, unlike Kristin, she has developed a plan which incorporates the typical family model in West Germany.

\title{
12.4.4 Karen from Lübeck: Planning a Family with a Gender- Related Role Allocation: "It Will be One of Those Modern Relationships, Where the Husband Works Somewhere else During the Week and Comes Home Over the Weekend"
}

Karen is 30 years old and lives in a town in West Germany not far from Lübeck. She has been with her partner for 7 years, and after years of seeing each other only on the weekends they have been living together for the past 3 years. At the time the interview took place she was certain that he was going to take up a new post soon, and that they would again see each other only on the weekends.

After graduating from high school Karen attended a business school in Lübeck. She then attended university in another town in West Germany. As she was unable to choose a single field of study, she pursued multiple fields. With such broad qualifications it was easy for her to find a job after she had completed her studies. Although this job was not well paid, it offered her the opportunity for further training over several years, and was a very good career move. Nevertheless, she left the job after 3 months: 
"I did it for three months, and enjoyed it (...) but then I thought, nah, this way is somehow too long for me, again three, four years of further training, so little money the whole time (...) it was just such a long way, and slowly but surely the idea emerged that I want a family at some point. If I take this long before I can even start, then I am eventually 35 and then I want children, then I finally want to start having children."

Karen then found another temporary job which promised to advance her career. However, she left this position as well after a short time as it seemed to be incompatible with her desire to have a child in the near future. She now has an open-ended job which does not offer great career opportunities, but which provides the perfect conditions for having a child:

"One reason I took this job was because it was open-ended, which means I have a certain security and can switch to part-time anytime I want, and that I am staying here [in the town where I currently live], so the next thing in line is having children, planning a family. And I can foresee doing this within the next year, somehow. The next deadline-because it didn't work out by 29-is now to have the first child by 32 at the latest."

This ideal of working part-time (if at all) after becoming a mother is in line with the traditional family model in West Germany. Karen, like Miriam from Lübeck, has a precise plan for becoming a parent, and has already put a great deal of effort into pursuing this objective. She has adhered to her plan of finishing her studies, then securing the right job, and then becoming a parent. This applies to her partner as well. From his interview we know that initially he did not want to start a family, and did not plan his career with the goal of supporting a family. He gradually changed his attitude, in part because he was persuaded by his girlfriend. He made job-related changes to ensure that he could fulfill his role as the breadwinner of the family. He reports:

"It is really like this, that I was at least implicitly as well as explicitly raised to believe that the most important goal is to have a job and to have money. And actually I was opposed to this view in the 90s; previously I was afraid that I would become unemployed, because in school I was interested in subjects like history, which are not really relevant for work...I have always been a potential candidate for unemployment. And this has indeed left a mark on me, so I went back and forth [from fear of unemployment to opposing a well-paid and secure but boring job]."

After completing vocational training, he did not work in his profession, but became a freelance artist:
"And then it was actually important to me to live as an artist, well to get around a lot, but I haven't thought that I could support a family, because it was obvious that I can only take care of myself then. But this has changed now, since I got together with Karen. Yes at first I was still a bit uncertain, but since I got together with Karen the model of having a family is there for me. That means responsibility for others, that also means that money has to be earned. (...) Now it is more important for me that I also earn money and that I am taken up on my duties as a father. This is my perspective, especially now. That is also the most impor- tant to me. We want to start a family, and that is great."

This interview excerpt shows how Karen's partner came to accept the expectation that he would take on the role of the main breadwinner when he became a father, even though he had rejected the role for years after having grown up with it. He now 
believes that he has found an opportunity to combine his desire to have an interesting and varied job with his role as the family breadwinner by pursuing a career as a scientist. Under the couple's long-term plan, Karen and the child will live in Lübeck or in the town where they are currently living, while her partner will live elsewhere during the week in order to pursue his career. At the center of the plan is the motherchild-home unit, which will remain in one place. Karen refers to it as "the principal life residence." In contrast to Kristin from Rostock, Karen is not worried at the prospect of being a single mother during the week.

Karen has already talked to her parents and friends about her plans for having a family, and knows that she will be supported by them. In addition, the career and stable income of her husband are more important to her than being able to live with him. Using this approach, she expects to succeed in combining the traditional West German family model with the flexibility and mobility currently demanded in the labor market. Unlike Kristin from Rostock, who has been unable to find a way to follow the egalitarian family model by pursuing a career in science while being a parent, Karen has found a solution by modifying the traditional West German family model. She is willing to give up her own career and living with her partner, and has asked her husband to focus on his career instead. Her husband's willingness to sacrifice spending time with his children in order to pursue his career and fulfill his role as the family's breadwinner is also in line with this model.

\subsection{Shared Living Conditions: Differing Conceptions and Behavioral Patterns}

The women from East and West Germany who were interviewed in this study were similar in terms of their initial positions and their current material living conditions: they described having difficulties related to their uncertain employment situations, including having to take temporary jobs and make frequent moves. The women also complained of challenges in figuring out how to reconcile having a family life with having an active and satisfactory work life. Nonetheless, we found that the women in the East and the West had very different ideas and behavioral patterns which, given these living conditions, could lead to childlessness.

Our comparison of four individual case studies sheds light on some behavioral patterns that have emerged from the different socialization contexts that prevailed in Germany prior to unification. In particular, we have been able to illustrate that the family models that were dominant in the former East and West Germany were still very present in the narrations of the women interviewed. While the East German women assumed that both parents would have a job, their West German counterparts assumed that there would be an asymmetric role allocation: i.e., that the man would be the main breadwinner and the woman would be primarily responsible for homemaking. It is thus apparent that women from East Germany see work and family life as being two parallel tracks, neither of which should have priority. There was 
no indication that they had even considered following the West German family model.

Given the current levels of economic uncertainty and the labor market demands that workers remain flexible as well as mobile, the East German family model has the potential to result in childlessness, as it is difficult to ensure under these conditions that both partners will be able to reconcile their work life with parenthood. Yet the West German model, in which the man's job is the sole focus, could also lead to childlessness if the male partner is unable to be the main breadwinner due to adverse labor market conditions. Thus, the East German egalitarian model seems to be more advantageous because both partners are contributing to the family income.

Another difference between the interviewees from East and West Germany was the degree to which they had planned how they would start their family. The West German women developed clear ideas about how they would like to reconcile work and family life, and about the role their partner was supposed to play. The East German women, by contrast, considered having a family to be a project that was independent of their work life, and did not develop any special plans regarding their own career or their partner's choice of profession or career (as was the case with Miriam and Karen from Lübeck). In line with the habitus concept, we reason that this difference may be traced back to the fact that women in the GDR did not have to engage in long-term planning to advance their own career and to ensure that they could reconcile employment and family life. The young women from Rostock lacked the experience of normative pressure, including the example of the preceding generation, which may have otherwise led them to formulate long-term plans even before they were ready to have children (Antje). Thus, they were not prepared to address the issue of how to reconcile work and family life when they were ready to start a family (Kristin). It is also conceivable that the absence of long-term planning was a response to unification and its consequences, as this event was both unexpected and uncontrollable for the individual. The fundamental social changes induced by unification shook up the current lives of many East Germans, as well as their expectations concerning their future lives. Having witnessed how quickly biographical continuity can be destroyed may have led them to avoid making long-term plans. Given the ongoing labor market uncertainties in Germany and the increasing demands for individual flexibility and mobility, following a long-term plan may seem difficult. Overly rigid biographical plans-e.g., setting subjective preconditions which must be fulfilled prior to family formation-may cause women to postpone parenthood, and to end up childless. However, an absence of long-term planning can also hamper the spontaneous realization of parenthood. By hoping the circumstances will be better at some point in the future, starting a family may be perpetually delayed.

These results confirm our hypothesis that an inertial effect of socialization under different political regimes is having long-term effects on the life paths of the generation under study. Although their current life conditions are similar, their different socialization contexts lead women to cope with these conditions differently. To gain a better understanding of different paths to childlessness, we therefore have to take into account the different perspectives and behavioral patterns that have persisted in East and West Germany even after unification. The interesting question which fol- 
lows from these observations is how durable this inertial effect is likely to be. Will we see fundamental changes in the cohort who are currently thinking about family formation, and who have been raised in unified Germany? Or will the inertial effect linger until the following generation-i.e., the young adults whose parents have not experienced a divided Germany_-start having children? These are interesting issues for future research.

Acknowledgement The authors thank Holger von der Lippe, Andreas Klärner, Christin Schröder, and Tina Hannemann for their valuable comments on this essay. This publication benefited from the support of the Swiss National Centre of Competence in Research LIVES-Overcoming vulnerability: life course perspectives, which is financed by the Swiss National Science Foundation. The authors are grateful to the Swiss National Science Foundation for its financial assistance.

\section{References}

Beck-Gernsheim, E. (1997). Geburtenrückgang und Kinderwunsch—die Erfahrung in Ostdeutschland. Zeitschrift für Bevölkerungswissenschaft, 22, 59-71.

Bernardi, L., von der Lippe, H., Klärner, A. (2006). Perceptions of job (in)stability and parenthood perspectives. Case studies in eastern and western Germany. Paper presented at the Population Association of America 2006 Meeting.

Bernardi, L., Keim, S., \& Klärner, A. (2014). Social networks, social influence, and fertility in Germany: Challenges and benefits of applying a parallel mixed methods design. In S. Domínguez \& B. Hollstein (Eds.), Mixed-methods social networks research. Design and applications (pp. 121-152). Cambridge: Cambridge University Press.

Bourdieu, P. (1984). Distinction. A social critique of the judgement of taste. Cambridge, MA: Harvard University Press.

D'Andrade, R. (1997). Schemas and motivation. In R. D'Andrade \& C. Strauss (Eds.), Human motives and cultural models (pp. 23-44). Cambridge: Cambridge University Press.

Eberstadt, N. (1994). Demographic shocks after communism: Eastern Germany, 1989-1993. Population and Development Review, 20, 137-152.

Falk, S., \& Schaeper, H. (2001). Erwerbsverläufe von ost- und westdeutschen Müttern im Vergleich: ein Land-ein Muster? In C. Born \& H. Krüger (Eds.), Individualisierung und Verflechtung. Geschlecht und Generation im deutschen Lebenslaufregime (pp. 181-210). Weinheim/München: Juventa.

Huinink, J., Kreyenfeld, M., \& Trappe, H. (2012). Familie und Partnerschaft in Ost- und Westdeutschland. Eine Bilanz. In J. Huinink, M. Kreyenfeld, \& H. Trappe (Eds.), Familie und Partnerschaft in Ost- und Westdeutschland. Ähnlich und doch immer noch anders (pp. 9-28). Opladen: Budrich.

Kreyenfeld, M. (2003). Crisis or adaptation-reconsidered: A comparison of East and West German fertility patterns in the first six years after the "Wende". European Journal of Population, 19, 303-329.

Kreyenfeld, M. (2004). Fertility in the FRG and GDR. Demographic Research, Special Collection, 3, 67-318. http://www.demographic-research.org.

Kreyenfeld, M., \& Konietzka, D. (2010). Nichteheliche Geburten. In J. Goldstein, M. Kreyenfeld, J. Huinink, D. Konietzka, \& H. Trappe (Eds.), Familie und Partnerschaft in Ost- und Westdeutschland (pp. 8-9). Rostock: Max-Planck-Institut für demografische Forschung.

Statistische Ämter des Bundes und der Länder (Federal Statistical Office and the statistical offices of the Länder). (2015). Kindertagesbetreuung regional 2014. Ein Vergleich aller 402 Kreise in Deutschland. Wiesbaden. 
Statistisches Bundesamt (Federal Statistical Office). (2012). Geburten in Deutschland. Ausgabe 2012. Wiesbaden. https://www.destatis.de/DE/Publikationen/Thematisch/Bevoelkerung/ Bevoelkerungsbewegung/BroschuereGeburtenDeutschland0120007129004.pdf.

Therborn, G. (1980). The ideology of power and the power of ideology. London: Verso.

Wenzel, S. (2010). Konvergenz oder Divergenz? Einstellungen zur Erwerbstätigkeit von Müttern in Ost- und Westdeutschland. Gender, 2, 59-76.

Witte, J. C., \& Wagner, G. G. (1995). Declining fertility in East Germany after unification: A demographic response to socioeconomic change. Population and Development Review, 21, $38-48$.

Witzel, A., \& Kühn, T. (2001). Biographiemanagement und Planungschaos. Arbeitsmarktplatzierung und Familiengründung bei jungen Erwachsenen. In C. Born \& H. Krüger (Eds.), Individualisierung und Verflechtung. Geschlecht und Generation im deutschen Lebenslaufregime (pp. 55-82). Weinheim/München: Juventa.

Open Access This chapter is distributed under the terms of the Creative Commons Attribution 4.0 International License (http://creativecommons.org/licenses/by/4.0/), which permits use, duplication, adaptation, distribution and reproduction in any medium or format, as long as you give appropriate credit to the original author(s) and the source, provide a link to the Creative Commons license and indicate if changes were made.

The images or other third party material in this chapter are included in the work's Creative Commons license, unless indicated otherwise in the credit line; if such material is not included in the work's Creative Commons license and the respective action is not permitted by statutory regulation, users will need to obtain permission from the license holder to duplicate, adapt or reproduce the material.

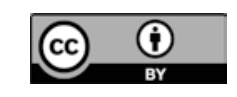

